\title{
Turning Inward: Using Insight as a Catalyst for Change in "The Corrections"
}

\author{
Nicholas Manai
}

Jonathan Franzen's The Corrections is a novel of self-correction in which characters struggle to resolve psychological difference in order to better assimilate themselves into the nuclear family. Through the course of the narrative, the ability to gain a deep and accurate understanding of one's self or another person, what I will call insight, leads to a broad moral perspective and is the catalyst for meaningful change in each of the three Lambert children's lives. Insight is not merely an awareness of identity, but also the ability to detach the mind, however slightly, from one's self in order to reflect on present circumstance. This thematic suggests that, for Franzen, the mind has important introspective powers that are separate from a genetic determinism grounded in instinct. But the insight produced by the mind is not separate from sensory experience because it is a focused awareness of circumstance which enables thought. The insight produced by this kind of reflection grants Franzen's characters the ability to effect meaningful change in their narratives. A reading of the novel that foregrounds insight in this way reconfigures the determinism that critics often find in the novel's resolution. Joseph Carroll, a bio-critic who uses an evolutionary framework to read against Franzen's Foucauldian thematics, argues that the children exist in opposition to the family unit and reconciliation at the denouement is forced for dramatic effect. Similarly, James Woods, who takes issue with Franzen's commitment to the social novel, argues that although "correction" is conceived as a struggle against determinism, the family ultimately swallows up the children's individual autonomy. These readings situate the novel as a fatalistic engagement with the set of socioeconomic factors that constrict individual liberty in the neo-liberal nation state of 2001. But the process of correction achieved from insight is a traceable thematic structure which asks characters not to ignore difference, but rather to turn inward and understand it, thereby embracing the otherness that makes them singular. 
Insight is best surmised by Sylvia Roth, whom Enid Lambert befriends aboard the cruise ship the Gunnar Myrdal. Roth's statement closely mirrors the scenes of correction in the novel, thus her words speak explicitly to Franzen's thematic project: "absolutely nothing changes except that you see things differently and you're less fearful and less anxious and generally stronger as a result: isn't it amazing that a completely invisible thing in your head can feel realer than anything you've experienced before?" (305). Throughout the novel, Chip, Denise and Gary are depicted in scenes where they suddenly "see things differently" and as a result they loosen strict, uncompromising moral perspectives and are able to imagine new ways to respond to problems in their lives (305). Chip Lambert believes that his recent failure to achieve tenure and subsequent expulsion from D-College is the result of an institutional conspiracy, and he decides he must expose the people involved for vindication. Denise believes unequivocally in her father's brilliance and her mother's inferiority, making cohabitation with her mother continually fraught with frustration and anger. The eldest son, Gary, is clinically depressed, but refuses to consider admitting his depression to his wife. The personal shame and separation from the family unit caused by these perspectives is medicated by drugs, sex, self-inflicted pain, and mind-numbing work. These moments provide a momentary escape from anxiety. They decrease self-awareness and the ability to think and feel deeply about other people. Their inability to effectively change a situation strengthens the thematic importance of self-awareness and insight, which does change the way characters feel about themselves and relate to others. Roth stresses the novel's reliance on introspection, saying, "the event, the big change in your life, is simply an insight," establishing the novel's embrace of personal responsibility, which places it at odds with trends in contemporary fiction that fragment subjectivity (305).

Marilynne Robinson's defense of individual reflection makes the case for rejecting the dominance of modern scientific logic at the expense of self-awareness, a position seemingly echoed in Franzen's novel for its emphasis on the mind's powers of perception. Robinson argues that if the mind can "know and seek to know itself in ways analogous to its experience of the world, then there are more, richer data to be gleaned...from every moment of introspection, of deep awareness of the self" (Robinson 120). Chip, Denise and Gary Lambert's corrections in the novel are the result of earning the "ric [h] data" to be gleaned after they "seek to know," what Roth calls "see[ing] things differently" (Robinson 120; Franzen 305). Robinson believes this process can be a catalyst for meaningful change, saying the mind can "negotiate its own enhancement" through self-awareness the same way microorganisms choose helpful genes from organic material. This thematic aligns Robinson, and Franzen as well, with Michel Foucault's understanding of subjectivity and ethics in the Greek and Roman city-states. Foucault argues that while "the care of the self" has become suspect as a form of self-love in modern society, at an earlier time "concern with the self and care of the self were required for right conduct and the proper practices of freedom" (285). Foucault juxtaposes the importance of individual freedom for the Greeks and Romans with the more modern view that the individual is "of no importance when placed against the imposing totality of the city" (285). Foucault's influence on Franzen has typically been reduced to the manifestations of power and 


\section{IJCS}

correctional facilities that abound in the novel and are evocative of Foucault's conception of repression early in his career. But the attention to insight as a process by which characters can care for themselves also aligns The Corrections with the later Foucauldian ethical system that considers awareness of the self to be an important way to practice human freedom.

Attention to the psychological processes of characters in this way supports Rachel Greenwald Smith's conception of the "affective hypothesis" in fiction, which "casts feeling as necessarily owned and managed by individual authors, characters, and readers" (2). Smith, whose book Affect and American Literature in the Age of American Neoliberalism engages specifically with The Corrections in its introduction, is critical of novels that privilege the subjectivity of emotions because she believes the way "previously nonmarket-oriented forms of life become understood as best functioning according to a market logic" bolsters neoliberalism (5). This thematic is most clearly demonstrated when Gary tries to read and manipulate different indicators of his mental health as though they were the stocks he buys and sells in the financial marketplace. But while this example exposes the farce of a self-managerial psychology, Smith argues that the rest of Franzen's narrative supports this ethos uncritically and therefore supports a neoliberalism reliant on individualization to support its brand of market capitalism. Instead, Smith offers a return to "ecological" fiction whose attention to "non-human actors" can create "impersonal affects" that disrupt the neo-liberal hegemony. This view is similar to Carroll's embrace of a biocultural ethics where values are the product of evolutionary necessity, which negate the possibility of the "Foucauldian cultural critique... where things are what they are because we... describe them in one way or another" (90). In both cases these critics seek to delegitimize the introspective powers of the mind as a source of correction.

Smith's critique of insight centers around the way The Corrections presents the individual as a "self-moderating market - as working autonomously from the effects of the others who surround them," and their dislocation from the other members in their family provides the novel its most ironic energy. Smith therefore finds the process of correction to be entirely alienating, in both practice and effect, creating the context in which the "enlargement of the single human being in the novel is the diminishment of the network of associations that inform the relative successes and failures of each individual member of a family" (10). While I agree that the process of correction is presented as an inherently individual phenomena in the novel, and also agree that, especially in the first half of each character's narrative, these processes seem to lead to the reduction of associations, it is my contention that insight produces a strengthening of familial and societal ties rather than a diminution of them, resolving difference through introspection. In this way knowledge of the self, in the manner of a Foucauldian subjectivity, is emphasized as a catalyst for meaningful change. Chip's episode is specifically evocative of the way insight informs the process of selfknowledge and is perhaps the reason his correction appears to be the most complete by the end of the novel.

Although Chip's character arc reconfirms him within the family, the process of insight reveals his transformation is not the product of a simple capitulation to his parents' Midwestern values. Instead, his narrative illuminates a richer psychological 
process whereby he comes to terms with his failures. This process is first blocked by decreasing awareness of inner waves of shame and disappointment with pain, sex and drugs. Robinson believes this kind of consciousness is necessary for correction. She writes, the "unimpaired brain has the degree of detachment necessary to report to us when our behavior might be...inappropriate" (119). When Chip picks his parents up from the airport he pulls on a rivet in his ear to escape the anxiety his parents prescience brings him, unsure if "the maximum pain his ear's nerves could generate was less pain than he needed now to steady himself" (Franzen 15). Chip's girlfriend Julia also remarks how he uses "sex as a kind of medication," and at the airport he believes imagining sex with a young girl "once every minute for as long as his parents [are] in town" is the only way to survive their visit (15). Both sex and pain are ways to feel "other," to reduce self-awareness, which is Chip's stated reason for smoking marijuana (117). For Foucault they also represent a subjectivity that is a "slave of [its] appetites" because Chip has not learned "to master the appetites that threaten to overwhelm one" $(288,285)$. These coping mechanisms relieve him of consciousness when he is ashamed of his parent's judgment and evoke the "affective hypothesis" through the alienation of a subjectivity striving to manage its own emotions (2). However, allowing his unimpaired mind to report, what Robinson calls meaningful data, will ultimately help Chip change his point of view.

Introspection is not only blocked by sex and drugs, but also through a strict moral perspective which does not allow him to conceive of alternate possibilities. Although Smith believes that attention to personal feelings heightens emotional isolation, the novel also represents strict perspectives as an equally alienating problem for its characters. After Chip is fired from his teaching position, we are told "anger carried him through the difficult weeks that followed" and in those weeks he "conceived revenge in the form of a screenplay that would expose the narcissism and treachery of Melissa Parquet and the hypocrisy of his colleagues" (87). At this moment, Chip sees his life as a tragedy and does not admit his own role in his failures. His sole purpose at this moment is to make "the people who hurt him see the movie, recognize themselves, and suffer" (87). He does not imagine he may have acted immorally, even ridiculously, and this strict interior construction renders him able to conceive of only one path for himself: vindication. His mind could be thought of as impaired by anger. Chip even reshapes Melissa's spoken words at the motel ("I love myself... what's wrong with that?") to make Mona, the character based on her in his screenplay, say something vain and conceited ("What's wrong with being in love with myself?") (66, 110). When the script becomes another failure, Chip accepts an offer to work in Vilnius because of "the prospect of getting on a plane and putting five thousand miles between himself and the nightmare of his life in New York City" (117). Vilnius offers the same solution as drugs, sex, and pain - the opportunity for "jailbreak" from the self that decreases self-awareness, limiting his ability to correct his painful circumstances (117). However, in Vilnius Chip will begin the process of correction when he broadens his perspective of the past, allowing him to construct a new interpretation of himself, which leads to a more peaceable connection with his family.

Through insight, Chip exemplifies the importance Foucault places on knowing oneself as a foundation of ethics. Foucault argues that for the Greeks "concern with 


\section{IJCS}

the self and care of the self were required for right conduct and the proper practice of freedom" (285). Although Chip's insight is playfully alluded to as a "great revelation," it is merely the understanding that his problems do not exist on a tragic scale (533). On the road to Poland from Vilnius, Chip's boss Gitanas alludes to Marx with the quip "a tragedy rewritten as a farce" (534). This quip helps Chip finally let go of this revenge fantasy because he realizes his life is not a tragedy and he sees the ridiculousness of his script. In this farce, which allows him to come to know himself, Chip regains the capacity to imagine a wider range of possibilities for his life than were allowed by a strict moral view. The strict view only allowed him to imagine vindication and a hateful script, which is why "nobody, not even himself, had ever liked his screenplay" (Franzen 537). Robinson helps illuminate Chip's correction noting, "'the material' itself is an artifact of the scale at which we perceive." "The material" component of Chip's past life remains unchanged, what has changed is the way he perceives it (Robinson 126). When he looks at his life differently, in Roth's language, Chip gains a broader perspective which allows him to see a new possibility for his screenplay and his life.

The correction Chip's script undergoes speaks not only to the psychological importance of insight, but also to the way insight strengthens networks rather than increasing isolation. At the novel's beginning he is described as having a "nearly photographic mental concordance of those 124 pages," and is able to immediately tally the appearance of a single word in the manuscript and the pages it appears upon (27). Chip's manuscript is actually presented mid-paragraph, between sentences detailing his thoughts, inviting the reader to equate the screenplay with his perspective. Later, during Chip's long walk toward Poland, he is conscious of "feeling more than a little ridiculous" and only a few sentences later envisions his protagonist, who bears many similarities to Chip's past experience, as a "comic fool" (537). As Chip begins to understand the comic aspects of his own life, he chants to himself "make it ridiculous" and bears "down with a mental red pencil on his mental reconstruction of these pages... and in his mind the scenes became what they'd wanted to be all along: ridiculous" (537-38). It is not so much Chip's present or future that is ridiculous, but rather the past life he associates with failure. The screenplay which was originally unappealing to others, and to Chip himself, goes through the process of correction and becomes compatible, even enjoyable, to his social network. By having the "mental reconstruction" occur "in his mind," Franzen explicitly presents a conception of the self that is reliant on interior construction (537-38). This thematic is exactly the kind of individual based ideology Smith argues against in the introduction to her book because she thinks it produces more ironically isolated characters.

But by correcting an interior perspective Chip actually changes the way he interacts with his family and views himself at the novel's end, leading him to more peaceable relationships. Chip's sympathy for his father in the hospital and his decision to settle down and marry in the Midwest are external examples of the interior change he made to his perspective. In St. Jude, after his insight, Chip feels as though "there was so little to him that he couldn't even say whether his sister and his father were mistaken about him. He felt as if his consciousness had been shorn of all identifying marks and transplanted, metempsychotically, into the body of a steady son, a 
trustworthy brother" (546). Even if Chip does not readily believe he is substantial at this moment, he shows signs of resistance to his earlier prognosis, where there was nothing in his life that identified him as a man and he was a failure compared to his siblings in the eyes of his parents. By releasing himself from self-justification, Chip can begin to develop into a substantive person because he can now imagine that possibility with his less rigidly defined perspective. After Christmas he attends lovingly to Alfred in the hospital and allows his sister to forgive his debt because she pleads for this kindness from him. These are both examples of a "steady son, a trustworthy brother" (546). Through "care for the self" Chip is able to derive selfworth from being a brother and a son and, following Foucault, becomes more aware of his ethical responsibility to others (10). Although most of Chip's development is rooted in interior construction, his sister Denise's correction shows much more explicitly the way Franzen uses human relationships to build personal identity and self-worth.

In Denise's narrative, insight is also able to loosen a strict moral perspective when reflection is directed at another character and not one's own self. In the same way insight helped Chip change his perspective toward his life, Denise frees herself from an uncompromising perspective toward her mother, which helps her envision more possibilities for their relationship. Denise's perspective did not make her feel inadequate. Instead she felt angry and resentful. Insight does not eliminate these symptoms from the relationship, but it shows Denise ways to transform them by helping her understand their root. At the beginning of the novel the mother-daughter relationship is fraught with discord because Denise is unable to empathize with Enid. Her inability to understand Enid also denies Denise the possibility of using her mother as a source of strength and self-awareness when she contemplates her life outside of the family. Expanding her perspective to include Enid as an important part of her life suggests that insight does not increase solipsism as Smith argues, or promote the determinism of the family, but rather it adds to Denise's agency.

Denise's relationship with her mother encourages a humanistic reading of the self, in which relationships are depended upon for love but also for knowledge and a sense of purpose. This thematic structure is common to Franzen's conception of his literary projects. Speaking about his life and work he says, "what I came to consider [as] money in the bank was that people loved me, and that came to seem like the key to everything. Not merely creating characters who could function as psychological objects, but making sure that love was implicit in the relationship between the author and the character" (Weinstein 3). The love Franzen posits as the core of meaning is reliant on the mind's ability to understand another person, not merely to receive stimulus, which furthers the importance of awareness and introspection for his characters. When Denise increases her self-awareness after a deeper understanding of her mother's life, she is able to imagine a loving relationship with her mother as a part of her interior perspective.

Denise does not have this relationship at the beginning of the novel because she worships and respects her father while mocking and resenting her mother. She pities how Alfred must put up with her mother, but fails to notice the ways her father may have negatively influenced her mother's life. Gary notices the feelings Denise has for 


\section{IJCS}

Alfred when he observes: "Denise had bizarre and unshakable notions about the old man" (Franzen 195). Because Denise views her father with such uncompromising compassion, when strife arises in the family dynamic she blames Enid. Denise is described as "forever informing Enid that she was stupid" (62). When Enid encounters a set of pornographic photos in Chip's apartment, Denise condescendingly asks Enid if she knows what the photos are, unable to see this may be very uncomfortable for a mother. At a much later moment she remarks quite firmly that she, "could not remember a time when she had loved her mother" (424). The resentment she shows her mother echoes Chip's view of Melissa Parquet and his past colleagues. It is stringent and denies her the ability to imagine auxiliary possibilities.

Denise uses information she gathers at lunch with her parents to increase her selfawareness and imagine a new understanding of her parents' lives. Her insight does not reveal itself all at once in a climactic moment, but instead, like Chip traveling south to Poland, the insight requires time for reflection before "the true extent of the correction [Denise] was undergoing reveal[ed] itself' (424). While reflecting on the time she spent with her parents at Chip's apartment she makes the realization that "her father at the lunch table had looked insane" (424). Denise is then able to use this insight to challenge her previously held beliefs about her parents' lives. She realizes that "if [Alfred] was losing his mind, it was possible that Enid had not been exaggerating her difficulties with him" (424). Smith's contention that this kind of psychological management is ineffectual or detrimental robs the character of agency, whereas in the novel characters are able to take responsibility and adjusts their perspectives. The data Denise collects about her parents allows her to become "a quite different Denise," one who "nearly ran her hands down Enid's hips and thighs, nearly caved in and promised to come at Christmas for as long as Enid wanted" (424). The new self Denise notices is the different way she is responding to her mother and thinking about her situation. The novel describes the new Denise as a "Version 5.0," not the working "Version 3.2" or "Version 4.0," who is feeling intimacy with Enid (425). This detail stresses how important human relationships are to Franzen's project because changing the way Denise feels for her mother actually creates an entirely new version of herself. By putting Denise's correction in terms of an operating system update, Franzen presents the self not as a static product, but continually changing and using agency to adapt to the new information the mind seizes and analyzes.

It is important to note that in this scene the narrator foresees "there might have been hope for her if she could have stayed on the train, but it was a short ride to Philly, and then she was back at work and had no time to think about anything" (426). Franzen envisions a better outcome for Denise if she had been able to continue reflecting on her insight, to think, rather than using work, the way Chip used pain, sex, and drugs, to escape contemplation. Franzen encapsulates his own views on this subject, saying in an interview that "you withdraw from the world so as to be able to hear the world better and know yourself better" (Martin). When Denise immerses herself in work she disrupts the important work of the "unimpaired brain" which Robinson champions (119). Chip, stranded in Vilnius and then Poland, was given the time to complete an interior reappraisal. He possessed Robinson's "unimpaired brain," which synthesized rich data Chip could use (119). After her insight, Denise rushes straight back to her 
job where she numbs her mind with work. Franzen's commitment to the thematic of knowledge of the self as a way to care for the self separates him from the modern tendency to view that kind of attention as "a form of selfishness or self-interest in contradiction with the interest to be shown in others or the self-sacrifice required" (Foucault 284). Franzen's thematic also aligns his novel with Robinson's criticism for modern scientific logic's reductivist understanding of the mind's capabilities. Franzen's contention that "we are larger than our biology" is on display through his attention to his character's imaginative capabilities in The Corrections and may be one way of understanding why a biocultural critic like Carroll finds the novel unconvincing (Franzen ${ }^{1} 33$ ). For Carroll, "the elements of human nature... have been shaped by an adaptive evolutionary process" and therefore should not be aligned with the imaginative capabilities Franzen and Robinson stress (90).

Despite the shortened time for reflection, Denise's episode still portrays measurable benefits in Denise's life after her insight. After realizing her mother might not have been exaggerating Alfred's illness, she also considers that "Enid's problems did not go much deeper than having the wrong husband" (Franzen 424). Denise does not attribute Enid's problems to having a sick husband, but to the "wrong husband," meaning she believes Enid's life was difficult long before Alfred's illness. She earns what is in Robinson's description the "rich data" achieved through awareness when it becomes "possible that Enid wasn't entirely the embarrassing nag and pestilence that Denise had made her out to be" (424). Denise's change in the novel begins as a new perspective on her mother's life, but grows into a new way of responding to situations that involve Enid.

Now that she can imagine the possibility that problems in her parents' lives are not Enid's fault, she is able to take her mother's side in arguments. After her lunch with Gary at the Axon conference, she "surprised herself by defending not only Alfred but Enid as well in the arguments that followed" (424). By realizing her previous tendency, Denise discovers her prejudice to be favorable toward Alfred (424). The broader perspective Denise now has toward her parents allows her to use her imagination to put together a much deeper and more complete conception of her mother's life. After viewing the carved heart under her father's bench which reveals Denise's love-affair with one of Alfred's coworkers, she concedes "she felt sorriest for her mother" (524). It is unclear how Denise would have reacted when she still held "unshakable notions" about Alfred, but it seems unlikely she would have immediately pitied her mother and not her father (195). It is an important scene because it demonstrates how a new possibility allows her imagination to reappraise the past. With her imagination she realizes Alfred quit his job prematurely without his pension and then shrunk deeper into his shell of isolation because of the pain caused by her affair which helped make Enid's life much more difficult and lonesome. Much like Chip, her perspective constructs a new meaning from the past, but it also influences future decisions. She forgives the money Chip owes her and asks instead for him to stay in St. Jude because "Mom wants someone here" (548). When she realizes how

\footnotetext{
${ }^{1}$ C.f. How to be Alone, all subsequent references to Franzen's work will come
} from The Corrections. 


\section{IJCS}

much of a "nightmare" her mother's life has been she wonders how she could have let herself even eat well if she had been "unable to imagine how hard another's life was" (521). By selecting the word "imagine," Franzen emphasizes the importance of interior construction and stepping outside of a strict moral view.

The benefits of interior thought are also emphasized by Denise's lack of selfawareness before her insight. Knowledge of the self is not only a way to care for the self but also to strengthen her relationship with her mother. In New York, after her insight into Enid's life, Denise realizes she is "more alike Enid then she had ever dreamed" (423). In addition to her new perspective there are two important scenes that show how Denise could understand herself through her mother. In the first scene, Denise is out to dinner with her boss, Brian Callahan, and some of his friends when a "Famous Director" remarks how much he enjoys Denise's cooking (424). The director's praise makes Denise uncomfortable which is why she "changed the subject as fast as she could" (424). Later in life, if Denise wanted to examine why she does not feel comfortable talking about her success as a cook, she might realize that she gets this side of herself from her mother by examining the second scene. In this scene, Denise tries to give Enid a compliment when she tells her mother she is a much better cook than the Driblets, but Enid deflects her daughter's praise saying, "I'm a nothing cook. A big nothing" (99). Self-denial and exaggerated humility are traits Denise may have learned from Enid. At the beginning of the novel, however, she denies herself the chance to learn from her mother by always telling Enid she is "stupid" (62). At the end of the novel Denise, like Chip, shows exterior signs of an interior change when she invites her mother to New York, pays for a roundtrip ticket and then treats her to what Enid describes as "four wonderful days" (564). It is hard to imagine the Denise at the novel's beginning, maybe "Version 3.2," giving this gift to her mother (425). The exterior signs here represent a newly loving relationship made possible by a new perspective and not ironic isolation. The human relationship is also a source of future identity. Reconciliation with a family member is also at the center of Denise's older brother Gary's insight in the novel. This insight, which is rooted in an interior reappraisal of circumstances aligns it with Chip's correction, and the importance placed on the edifying effects of human relationships unites his episode with Denise's

correction. In keeping with the thematic structure of the novel, the reappraisal of circumstance creates new possibilities for the relationship between Gary and Caroline.

A character's points of view can also be dominated by important relationships in their lives to the point where they do not possess the agency to act freely. Although Gary begins the novel dominated by his wife's insistences, he discovers through insight the possibility of his own desires. Keeping the freedom to choose at the center of Gary's episode strengthens individual choice within the novel's thematic structure, but in a markedly different manner than the individual agency Gary shows when he acts as though his mental health were similar to market-forces. As Smith points out, Franzen is critical of the managerial approach Gary takes when he monitors his personal "Neurofactor[s]," yet for Smith, the novel actually confirms this kind of psychic behavior through the arc of Gary's episode (139). In my reading, the correction Gary eventually undergoes does not "enlarge the single human being in the 
novel" at the expense of his network of connections, but rather leads him back, if imperfectly, into his network through a reclaiming of agency (Smith 10).

At the episode's beginning, Gary negates his inner desires in order to conform to a strict definition of mental health. Gary will not admit he is depressed because "his entire life [is] set up as a correction of his father's life" (184). Since "he and Caroline had long agreed that Alfred [is] clinically depressed," admitting that he is depressed would allow Caroline to see a similarity between Gary and his father (184). To prevent this from happening, Gary believes he has "no choice but to keep resisting ANHEDONIA, keep gritting his teeth, keep doing his best to have fun" (181). Gary's strict view of difference toward his father does not allow him the freedom to make his own choices, namely uncovering his depression. Gary also subjects his autonomy to Caroline's perspective of mental health because in her he sees someone different from his parents. One of his favorite things about Caroline is how "unlike a Lambert, how fundamentally unsympathetic to his family" she is (184). Gary measures his difference to his father through Caroline's perspective. He has placed her comment "You're nothing like your father" in the number one slot on his "All-Time Caroline Ten, to which he privately referred for strength and sustenance" (184). Gary's strict perspective, therefore, is not even his own formation and is reliant on Caroline's definition of mental health. If she thinks he is depressed, then he is no longer "nothing like" his father (184). By continually placing Gary's major symptom, anhedonia, in all capitals, Franzen emphasizes how Caroline's definition of mental health becomes an overbearing presence in Gary's life. Gary is introduced to the "clinical term, ANHEDONIA" when he reads it in a book on Caroline's nightstand (165). Then he looks up the "dictionary entry for ANHEDONIA" and is worried he possesses this symptom of depression and Caroline will notice it (165).

Franzen depicts the subjugation of agency through the curtailment of freely chosen activities. The first time the reader meets Gary he is "trying to enjoy reprinting two old photographs of his parents, and by enjoying it, to reassure himself about his mental health" (Franzen 139). A character might try to enjoy a favorite hobby to shake off feelings of depression, but since he "doesn't need or want" the darkroom, Gary's attempt to medicate himself with a hobby that does not reflect his inner desires will only further alienate him from himself (142). It is also evocative of Foucault's insistence that the self become master of its own desires. When Gary was given the darkroom as a birthday present from Caroline "his impulse... was to weep" (142). However, Gary has also learned "from certain pop-psychologist books on Caroline's nightstand" that a sign of mental illness is the "proclivity to inappropriate weeping" so he swallows this impulse (142). The darkroom is an expensive present from his wife so it is entirely possible that weeping at this moment is appropriate. He might pity all of Caroline's hard work or be saddened that she did not understand his inner desire when undertaking the "All-Time Lambert Two-Hundred" photo album (142). But instead of actively following his impulse to cry he "swallowed the lump in his throat and bounded around the expensive new darkroom and exclaimed to Caroline...that he was utterly delighted with the gift!" (142). Here his inner desires are not expressed because he cannot imagine a possibility other than one that is in keeping with Caroline's view of depression. By "resolving to work in the darkroom 


\section{IJCS}

twice a week to...reassure himself that he wasn't clinically depressed and to make sure that Caroline never suspected anything of the kind," he presents a façade in keeping with the established narrative of "pop-psychologists," and avoids revealing anhedonia (142). At the beginning of Gary's episode his individuality is subjugated to strict influences, but the kind of psychological correction he achieves through insight, opens up the possibility of deeper connection with his network of relationships.

Personal freedom is important in Gary's episode in the way insight reveals the new possibility he had not previously considered. The night before his insight, after slicing his hand with a hedge trimmer while intoxicated, Gary "knew...he couldn't ask Caroline to drive him [to the hospital] without...paint[ing] the opposite of the picture of Good Mental Health that he'd intended to create" (232). Here Gary holds the same strict view of denial. The next morning, however, "a radical new plan took shape in Gary's brain... His radical new plan was to do absolutely nothing" (236). Here, absolutely nothing means not covering up depression or trying to enjoy activities he does not enjoy. This plan occurs only a few hours later, when "absolutely nothing [has] change[d]," as Sylvia Roth points out, except that he "see[s] things differently" (305). Although nothing material has changed, Gary has increased his self-awareness which Robinson defines as "primarily the self that stands apart from itself, that questions, reconsiders, appraises" (Robinson 118). On this morning Gary reconsiders his options. Previously he chose to hide the evidence of his depression, but now he chooses to reveal it. When Jonah comes to his room to ask if he is well, he does not say anything because he "had to inflict... his clinical depression, on the one creature he wished he could have spared" (Franzen 236). The difference between this action and the Gary who hid botched photography prints from Jonah in the darkroom to demonstrate a perfect, cheerful attitude is striking (141). Gary's physical actions in this scene finally become evocative of his interior feelings. Instead of manipulating his "Neurofactor[s]," he does not try to mop up the evidence or fake a smile. Rather than be determined by his biological response, Gary's embrace of reflection and thought reveals possibilities which unite him with his family rather than alienate him from this network.

Immediately after he admits that he is depressed, there "[is] a reward. He fe[els] Caroline's warmth approaching, its radiance, before she touched him" (237). Gary's reconciliation with Caroline echoes Denise's realignment with Enid and Chip's reconciliation with his father and his new wife. In both cases a loving human relationship gives pleasure, but also substantive worth to life. After feeling Caroline's "warmth," Gary "not only no longer felt depressed, he felt euphoric" (238). Instead of feeling "ostracized" he feels reunited with his family and, perhaps metaphorically, Caroline "put[s] a proper bandage" on his wound (237). Carroll argues that in this scene, after Gary has "voluptuous sex," he continues his "life-long trend of acquiescing to [Caroline's] psychological domination" (95). Woods agrees, finding that in the novel "family is the great determinism...the idea of correction [is] a doomed struggle against this determinism," echoing the sense that attention to the self leads to separation and the suppression of agency (Woods). Although Gary's correction does reunite him with the family dynamic, I would add he also regains a sense of his own autonomy. Through Gary, Franzen shows a character beginning to understand his self 
and practice his freedom which for Foucault is essential for constructing "new power relations" within which the individual can exist "in pleasure[able] relationships with others" (Foucault 284). In Franzen's novel, as well as in Foucault's ethics, the practice of freedom is linked to self-knowledge. While Gary is having sex with his wife "the thought came to him...that he was who he was, he was Gary Lambert, he had inappropriate thoughts and he was sick of apologizing" (Franzen 238). When Gary raises his self-awareness, he believes he can assert his autonomy and now asks Caroline for the money to make the investment he desires. At first the self is expressed when he buys stock, but later it will also be shown in the hobbies that represent his "inclinations" (82).

In this reading, the self is envisioned as a collection of interests and desires that find expression through hobbies. When Gary realizes "who he [is]" he lets himself admit that Gary Lambert doesn't like darkrooms but rather "O-gauge model railroad equipment" $(238,494)$. Martin Hipsky writes that Gary regains some "autonomy," but labels it "ineffectual" (Hipsky). Although there are signs of his continued dependence upon Caroline, I would point to his new hobby as an effective correction to the depressed man at the beginning of the novel. Now, "with the lifting of his 'depression,' he'd developed a new interest... and he could have spent a whole day - the whole week! - pursuing it" (Franzen 494). Gary plans to, "dismantle the darkroom....and build a model-railroad setup on the second floor of the garage" (498). Rather than putting himself under Caroline's thumb he is dismantling her gift and establishing a space for his independent interests. Gary even describes a day as "Gary's Recreation Day" and on this day Denise walks down the stairs in St. Jude to find "Gary, all smiles...with an O-gauge model railroad engine in his hands" (523). It is telling, perhaps even heavy-handed, the way the railroad set was "lost" for so long and now Gary is "glad [he] had the satisfaction of finding it" (523). Even more illustrative, yet perhaps more covertly conveyed, is that Gary's erection on the morning he makes love with Caroline after his confession of depression is described as being "as long and hard and heavy as an O-gauge model railroad engine" (238). The reader could take this wordplay to mean that the enjoyment of trains is associated with the admission he gives Caroline, the re-establishment of their love and the lifting of his depression. The insight which gave Gary the self-awareness to imagine a new possibility and admit his depression also helps him enjoy his hobbies again. When Gary is reunited with his wife he also remembers who he is, stressing the ways knowledge of the self and social integration are integrated. The way Gary reasserts his autonomy after growing in selfawareness points out how the self's desires need to be satisfactorily fulfilled with interests and hobbies.

The repeated stress Franzen grants to moments of insight that increase selfawareness and lead to a new perspective confirms a framework which guides each character's change from the person we witness at the novel's beginning to its end. Plot twists and dramatic action in these scenes, if present at all, are muted. Chip's circumstances come the closest to actually influencing his decisions and yet his correction is entirely a function of the way he constructs, or imagines, his life. Robinson's conception of self supports this reading by advocating a return to inwardness in our formation of the self and our conception of its myth. Scenes where 


\section{IJCS}

sex, drugs, self-inflicted pain, and mind-numbing work are used to escape shame and self-awareness permeate The Corrections to show how escaping inwardness hinders emotional growth. The reliance on inwardness may confirm a neo-liberal privileging of the individual, as Smith's introduction argues, but in The Corrections, inwardness also produces dramatic change for alienated characters that reunites them with their major source of identification, the family unit. Rather than separating them from their network, it bolsters a reliance on understanding their place in the social fabric while at the same time freeing the individual from conceiving of the self as the inevitable product of so many different circumstantial influences. The most important moments in a person's life are no longer events themselves, but the way the self perceives, decodes and understands those events.

\section{Works Cited}

Carroll, Joseph. "Correcting for The Corrections: A Darwinian Critique of a Foucauldian Novel." Style, vol. 47, no. 1, 2013, pp. 87-118.

Foucault, Michel. "The Ethics of the Concern of the Self as a Practice of Freedom." Ethics: Subjectivity and Truth, The Penguin Press, 1997.

Franzen, Jonathan. The Corrections. Farrar, Straus and Giroux, 2001.

Franzen, Jonathan. “My Father's Brain.” How to Be Alone, Farrar, Straus and Giroux, 2002.

Hipsky, Martin. "Post-Cold War Paranoia in The Corrections and The Sopranos." Postmodern Culture, vol. 16, no. 2, January 2006, http://pmc.iath.virginia.edu/issue.106/16.2hipsky.html.

Robinson, Marilynne. Absence of Mind: The Dispelling of Inwardness from the Modern Myth of the Self. Yale UP, 2010.

Smith, Rachel Greenwald. Affect and American Literature in the Age of Neoliberalism. Cambridge UP, 2015.

“The Scratch Interview with Jonathan Franzen.” Manjula Martin. N.p., 13 Oct. 2013.

Weinstein, Philip. Jonathan Franzen: The Comedy of Rage. Bloomsbury Academic, 2015.

Woods, James. "Abhorring a Vacuum.” New Republic N.p., 15 October 2001, https://newrepublic.com/article/76988/abhorring-vacuum. 